\title{
Impact of copper, pentachlorophenol and benzo[a]pyrene on the swimming efficiency and embryogenesis of the amphipod Chaetogammarus marinus
}

\author{
A. J. Lawrence*, C. Poulter \\ Department of Biological Sciences, University of Hull, Cottingham Road, Hull HU6 7RX, United Kingdom
}

\begin{abstract}
The effects of copper $(\mathrm{Cu})$, pentachlorophenol (PCP) and benzo[a]pyrene (B[a]P) on swimming efficiency and embryogenesis of Chaetogammarus marinus were examined. Swimming stamina against a pump driven head flow of water was significantly impaired at concentrations of $15 \mu \mathrm{g} \mathrm{Cu} \mathrm{l}^{-1}, 40 \mu \mathrm{gCP} \mathrm{I}^{-1}$ and $20 \mu \mathrm{g} \mathrm{B}[\mathrm{a}] \mathrm{P} \mathrm{l}^{-1}$. Development of in vitro cultured embryos was significantly impaired by $20 \mu \mathrm{g} \mathrm{Cu} \mathrm{l}^{-1}, 20 \mu \mathrm{g} \mathrm{PCP}^{-1}$ and $20 \mu \mathrm{g} \mathrm{B}[\mathrm{a}] \mathrm{P} \mathrm{l}^{-1}$. Cu and PCP extended the period of embryogenesis by 4 to $8 \mathrm{~d}$ while embryos cultured with B[a]P hatched at the same time as controls but were significantly smaller. Specific stages in the embryos' development were affected by each pollutant. Stage 1 was resistant to these effects but Stages 2 to 4 , in which the embryo undergoes development of the germinal disc, dorsal organ rudiments, cordal furrows, appendage rudiments and segments, eye and heart, were all prolonged in toxicant-exposed treatments. The time taken for Stage 5 of embryogenesis was generally reduced in pollutant exposed embryos. The results indicate that both swimming stamina and embryogenesis in C. marinus may be used as sensitive bioassays for toxic effects in estuarine areas. In the case of $\mathrm{Cu}$, the assays are responsive at environmental concentrations periodically experienced at some locations on the Humber estuary, United Kingdom. The swimming stamina assay has the advantage that it reflects the competence of the animals over a range of integrated physiological processes while the embryo assay has the advantage that effects at this level may reflect population level responses to pollution.
\end{abstract}

KEY WORDS: Chaetogammarus marinus - Swimming efficiency · Embryogenesis · Copper · Pentachlorophenol $\cdot$ Benzo[a]pyrene $\cdot$ Bioassay

\section{INTRODUCTION}

In previous studies a number of sub-lethal bioassays for a range of representative pollutants were developed and tested using the estuarine amphipod Gammarus duebeni (Lawrence \& Poulter 1996, 1998). G. duebeni is generally widely distributed in North Sea estuaries (Bulnheim 1979, Ritz 1980, Sheader 1983). However, populations of this species on the Humber estuary in the United Kingdom appear transient and consequently, according to the criteria developed by

*E-mail: a.j.lawrence@hull.ac.uk
Philips (1980), this species does not appear to be ideal for sub-lethal toxicity testing in this area.

A second species of amphipod, Chaetogammarus marinus, is also found on the Humber estuary, and populations of this species appear to be more stable. $C$. marinus is known to be a weak competitor at low salinities (Pinkster \& Broodbaker 1980) and has a characteristic life span of $1 \mathrm{yr}$ (Skadsheim 1982). It is known to have a low reproductive output (Vlasblom 1969) and generally occurs on saline estuarine shores. Like other Gammaridae, it has an important ecological role in these estuarine areas shredding vegetation and as one of the major food sources for fish (McLusky 1989). 
Bryan \& Langston (1992) highlighted the need to use more estuarine animals in ecotoxicological studies. Until recently, estimation of toxic impacts in estuarine areas was predominantly derived from experiments using marine species. However, recent studies have increasingly used estuarine species as test organisms (Lawrence \& Poulter 1996, 1998, Roast et al. 1998, 1999, 2000a,b, Baron et al. 1999). This is important because estuarine species may have distinctly different responses to pollution from their marine counterparts. Through their adaptation to the estuarine environment, they may either be pre-adapted to tolerate pollution stress or be more susceptible to any additional stress (Lawrence \& Poulter 1996).

Clearly the responses of estuarine species to pollution would be much more indicative of the impact of the pollutant in an estuary than are tests using marine species. Indeed, the studies by Lawrence \& Poulter (1996, 1998) indicate that swimming efficiency in Gammarus duebeni is significantly impaired at concentrations of $45 \mu \mathrm{g} \mathrm{l}^{-1} \mathrm{Cu}_{2} 20 \mu \mathrm{g} \mathrm{l}^{-1} \mathrm{PCP}$ and $8 \mu \mathrm{g} \mathrm{l}^{-1}$ $\mathrm{B}[\mathrm{a}] \mathrm{P}$. On the Humber, these $\mathrm{Cu}$ concentrations are periodically experienced at a number of sites. These studies further highlight the potential use of behavioural endpoints in ecotoxicology. This approach is well developed in the freshwater species G. pulex (Taylor et al. 1993, 1994) and effects of pollution on swimming behaviour have now also been determined in the estuarine mysid Neomysis integer (Roast et al. 2000a,b).

In addition to the need for more estuarine species to be used in ecotoxicology, recent studies have highlighted the need for more work examining the impact of pollution on reproduction and development (Lawrence \& Hemingway 2001). This issue has received a great deal of attention recently given the concern over endocrine-disrupting chemicals in the environment. Reproduction and development of many species are often the life history stages most sensitive to pollution and environmental change (Lawrence 1996). They are also the critical stages in the hierarchical levels of response by an organism to pollution that link molecular, sub-cellular and physiological responses to population and community impact. While the trend in recent years has moved towards the biomolecular and subcellular responses to pollution, it is often the population response that is critical especially in commercially important species. However, studies showing clear links between biomolecular response and population impact do not exist.

The aim of this study was 2-fold. First, to evaluate the potential role of the amphipod Chaetogammarus marinus as a test species in estuarine areas and to further develop assays for pollution at sub-lethal levels using this species. To determine this, the sensitivity of
C. marinus to $\mathrm{Cu}, \mathrm{PCP}$ and $\mathrm{B}[\mathrm{a}] \mathrm{P}$ was examined using the swimming bioassay previously developed by Lawrence \& Poulter (1998).

$\mathrm{Cu}$ is a heavy metal that has consistently exceeded its Environmental Quality Standard (EQS) at various sites on the Humber estuary. B[a]P is a heavy polycyclic aromatic hydrocarbon that is more persistent in the environment than the volatile components of oil pollution; consequently it serves as an indicator of other polycyclic aromatic hydrocarbons that contaminate the environment (Irwin et al. 1998). It is carcinogenic and has recently been identified as anti-oestrogenic (Safe 1995). PCP is a persistent priority pollutant in the USA (Irwin et al. 1998). A semi-volatile chlorophenolic compound, it is used in wood preservative and as a herbicide, disinfectant and anti-foulant (Eisler 1989). A degradation product of lindane and hexachlorobenzene, it is believed to be fetotoxic, embryotoxic and teratogenic to wildlife (Irwin et al. 1998)

Second, the sensitivity of Chaetogammarus marinus to sub-lethal pollution was further assessed by examining the impact of these representative pollutants on embryonic development. Gammaridae lend themselves well to studies of this type. Eggs are released into a marsupium or brood pouch before fertilisation and then go through 5 clear stages of development (Sheader \& Chia 1970).

\section{MATERIALS AND METHODS}

Chaetogammarus marinus were collected between mid-level and high water from a Fucus vesiculosus covered rocky area on the north shore of the Humber estuary near Paull. Test animals were maintained in shallow tanks of seawater diluted with double-distilled water to $20 \mathrm{psu}$ and kept in an aquarium at $11^{\circ} \mathrm{C}$. They were fed Enteromorpha, collected from the sample site. Individuals were measured from the head to the end of the third uropods using callipers, and individuals 15 to $21 \mathrm{~mm}$ in length were used as test organisms in the study.

$\mathbf{L C}_{\mathbf{5 0}}$ testing. Preliminary range finding and definitive $\mathrm{LC}_{50}$ tests were performed on Chaetogammarus marinus using anhydrous $\mathrm{CuSO}_{4}$ (Merck Eurolab Ltd, Poole, Dorset, UK) in seawater diluted to $20 \mathrm{psu}$. $\mathrm{LC}_{50}$ for PCP and $\mathrm{B}[\mathrm{a}] \mathrm{P}$ were determined as described by Lawrence \& Poulter (1998). In each case a static test system was used. Ten animals were used in each treatment and maintained in a plastic tray $(10 \times 14 \mathrm{~cm})$ in test medium. Test solutions were changed daily to prevent loss of the toxicant through absorption onto the walls of the tray.

Swimming stamina assays. The effects of sub-lethal concentrations of $\mathrm{Cu}, \mathrm{PCP}$ and $\mathrm{B}[\mathrm{a}] \mathrm{P}$ on the swimming efficiency of Chaetogammarus marinus were examined following the protocol developed by Lawrence \& Poul- 
ter (1996). Concentrations of $\mathrm{Cu}$ at 0,15 and $30 \mu \mathrm{g} \mathrm{l^{-1 }}$ (total $\mathrm{Cu}$ ) and 20 psu were used in the $\mathrm{Cu}$ assay. Concentrations of 0,40 and $60 \mu \mathrm{g} \mathrm{PCP} \mathrm{^{-1 }}$ and concentrations of 0,40 and $60 \mu \mathrm{g} \mathrm{B}[\mathrm{a}] \mathrm{P}^{-1}$ were also tested at 20 psu. Masterflex Tygon (Merck Eurolab) plastic flexitubing (bore diameter $7 \mathrm{~mm}$ ) was connected to the inlet and outlet of a peristaltic pump. The pump was used to set a flow rate for each test solution of $145 \mathrm{ml} \mathrm{min}^{-1}$. A scale was marked on the outlet pipe in millimetres at either side of a zero point. This allowed the positive or negative movement of each test individual, against the head flow of water, to be recorded. The flow rate was selected based on preliminary studies in which the individuals were found to be able to maintain their position or move against the head flow over a period of $5 \mathrm{~min}$. Each individual's swimming stamina was recorded at time 0 as it was initially introduced to its test solution and then at intervals over the next $180 \mathrm{~h}$. Movement was expressed as mm moved $\mathrm{min}^{-1}$. Individuals were placed into the outlet pipe at the zero mark and their movement was timed and recorded.

Embryo culture. Methods of embryo culture of Gammarus species have been described (Sexton 1928, Vlasblom \& Bolier 1971, Morritt \& Spicer 1995, 1996), and these were modified and adapted for use in the culture of eggs from Chaetogammarus marinus.

Pre-copula pairs were separated into containers containing $2 \mathrm{~cm}$ depth of 20 psu autoclaved seawater. The pairs were maintained in constant-light conditions and a temperature of $11^{\circ} \mathrm{C}$. Constant light has been found to produce a continuous breeding cycle with no resting stages in Gammarus lawrencianus (Steele 1981). Individuals were regularly fed Enteromorpha and monitored until the male had fertilised and released the female. The male was then removed. Immediately after deposition of eggs into the marsupium, the embryos were removed from the female. The individual's length was measured, and then it was pinned and the embryos were teased out through the setose oostegite using sterile mounted needles and fine nerve forceps.

Separate broods were then immersed in sterile 20 psu seawater for cleaning. Groups of 8 undamaged embryos from each brood were then transferred into separate sterile petri dishes. The cleaned dishes contained $10 \mathrm{ml}$ of autoclaved 20 psu seawater. They were placed on a slow moving self contained table in an aquarium maintained at $11^{\circ} \mathrm{C}$, ensuring that the embryos were constantly aerated and free from settling bacteria. Parafilm was used to cover the dishes to prevent bacterial infection and reduce evaporation while also allowing gaseous exchange to occur.

At daily intervals, 8 embryos were carefully removed from each culture using a sterile pasteur pipette. The embryos were placed onto a slide in test medium and measured using a calibrated optical graticule on a light microscope. Maximum width and length of each embryo were measured since they are ellipsoid or prolately spheroid (Sheader \& Chia 1970). During measurement the 'Stage' of embryo growth was also noted as described by Sheader \& Chia (1970): Stage 1: There is early cleavage before germinal disc formation. The cells are all pigmented; Stage 2: The germinal disc develops and dorsal organ rudiment appears; Stage 3: The caudal furrow forms and appendage rudiments appear; Stage 4: Appendage segmentation is apparent, the dorsal organ is reduced, the optic rudiment and heart (still) develop, the caudal furrow widens, and the embryo has a more oval shape as the head occupies the apex; Stage 5: Red pigment spots appear on the eye rudiments, the heart now beats, the dorsal organ is further reduced, and muscular movement is apparent, especially in the gut; Stage 6: The juvenile hatches into the brood chamber or marsupium.

Test solutions were changed during measurement so that embryos were returned to a sterile environment. Observations were continued until either development ceased due to disruption or the first juveniles hatched. Sheader (1995) observed that individuals of Gammarus insensiblis hatched within 3 to $4 \mathrm{~h}$ of others in the same brood. During the test period degenerate embryos were removed from the culture.

Effect of $\mathrm{Cu}$ on embryo growth and development. To determine the effect of $\mathrm{Cu}$ on embryo growth and stage duration, the in vitro culture method described above was followed and the maximum lengths of developing embryos were measured in test media of 0 , 20 and $40 \mu \mathrm{g} \mathrm{Cu} \mathrm{l}^{-1}$ autoclaved 20 psu seawater. Cultures were maintained at $11^{\circ} \mathrm{C}$.

Effect of PCP in embryo growth and development. Using autoclaved 20 psu seawater, $100 \mathrm{ml}$ of $40 \mu \mathrm{g}$ PCP $1^{-1}$ was made up as described by Lawrence \& Poulter (1998). The culture method described here was then followed using test solutions of 0,20 and $40 \mu \mathrm{g} \mathrm{PCP} \mathrm{l}^{-1}$ by appropriate dilution of the stock. Maximum length of embryo and stage duration were measured throughout the study.

Effect of B[a]P on embryo growth and development. Using autoclaved $20 \mathrm{psu}$ seawater, $100 \mathrm{ml}$ of $40 \mu \mathrm{g}$ $\mathrm{B}$ [a]P $\mathrm{l}^{-1}$ was prepared as described by Lawrence \& Poulter (1998). The culture method described here was then followed using test solutions of 0,20 and $40 \mu \mathrm{g}$ $\mathrm{B}[\mathrm{a}] \mathrm{P}^{-1}$ and embryo length and stage duration were measured throughout the test.

Statistical analyses. Probit analysis (Finney 1980) was used to determine $\mathrm{LC}_{50}$ values, and $95 \%$ confidence intervals for each of the pollutants were used in the study. Results from swimming and embryo development assays were examined using 1- and 2-way ANOVA and an a posteriori least significant difference (LSD) tests. 


\section{RESULTS}

$$
\mathrm{LC}_{50} \text { tests }
$$

$\mathrm{LC}_{50}$ values for $\mathrm{Cu}, \mathrm{PCP}$ and $\mathrm{B}[\mathrm{a}] \mathrm{P}$ are shown in Table 1. The $48 \mathrm{~h} \mathrm{LC}_{50}$ values were $40 \mathrm{\mu g} \mathrm{l}^{-1}$ for $\mathrm{Cu}$, $258 \mu \mathrm{g} \mathrm{l}^{-1}$ for PCP and $158 \mu \mathrm{g} \mathrm{l}^{-1}$ for B[a]P. Of the toxicants used in the study, therefore, Chaetogammarus marinus was found to be most sensitive to $\mathrm{Cu}$ and least sensitive to PCP.

\section{Swimming stamina assays}

Results of the tests examining the impact of $\mathrm{Cu}$ on the swimming stamina of Chaetogammarus marinus are shown in Fig. 1. Control individuals displayed a swimming rate fluctuating between -30 and $+50 \mathrm{~mm}$ $\mathrm{min}^{-1}$. At $15 \mu \mathrm{g} \mathrm{Cu} \mathrm{l}^{-1}$, swimming efficiency was significantly impaired after approximately $100 \mathrm{~h}$ of exposure. After $136 \mathrm{~h}$, swimming stamina continued to decrease and reached an average level of $-78 \mathrm{~mm}$ $\min ^{-1}$ at $176 \mathrm{~h}$. In $30 \mu \mathrm{g} \mathrm{Cu} \mathrm{l} \mathrm{l}^{-1}$ swimming efficiency decreased significantly after $60 \mathrm{~h}$ of exposure. This was reduced to an average of $-170 \mathrm{~mm} \mathrm{~min}^{-1}$ at the end of the test period.

Two-way ANOVA showed that the effects of $\mathrm{Cu}$ and time were significant $(F=31.9, \mathrm{p}<0.001, \mathrm{df}=15)$. There were significant concentration $(F=138.3, \mathrm{p}<$ $0.001, \mathrm{df}=2)$ and time effects $(F=15.5, \mathrm{p}<0.001, \mathrm{df}=$ 13), and significant interaction between the $2(F=8.4$, $\mathrm{p}<0.001, \mathrm{df}=26$ ). An a posteriori LSD test gave a complex pattern of differences based on $\mathrm{Cu}$ and time interactions. Consequently, a 1-way ANOVA was used to confirm the significant difference between the treatments $(F=48.5 \mathrm{p}<0.001, \mathrm{df}=2,207)$ and an a posteriori LSD test showed that the difference between each treatment was significant at the $p=0.05$ level.

Results of the effect of PCP on the swimming stamina of Chaetogammarus marinus are shown in Fig. 2. On exposure to $40 \mu \mathrm{g} \mathrm{PCP} \mathrm{l}^{-1}$ swimming stamina was ini-

Table 1. Chaetogammarus marinus. $\mathrm{LC}_{50}$ values for copper $(\mathrm{Cu})$, pentachlorophenol $(\mathrm{PCP})$ and benzo[a]pyrene $(\mathrm{B}[\mathrm{a}] \mathrm{P})$ at $11^{\circ} \mathrm{C}$ and 20 psu. $\mathrm{n}=10$

\begin{tabular}{|lcc|}
\hline Pollutant & $\mathrm{LC}_{50}\left(\mu \mathrm{g} \mathrm{l}^{-1}\right)$ & $\begin{array}{c}\text { Probit range } \\
95 \% \mathrm{CI}\end{array}$ \\
\hline $\mathrm{Cu}$ & $24 \mathrm{~h}=50$ & $43-75$ \\
$\mathrm{Cu}$ & $48 \mathrm{~h}=40$ & $32-53$ \\
$\mathrm{PCP}$ & $24 \mathrm{~h}=416$ & $361-494$ \\
$\mathrm{PCP}$ & $48 \mathrm{~h}=258$ & $206-312$ \\
$\mathrm{~B}[\mathrm{a}] \mathrm{P}$ & $24 \mathrm{~h}=441$ & $392-528$ \\
$\mathrm{~B}[\mathrm{a}] \mathrm{P}$ & $48 \mathrm{~h}=158$ & $114-201$ \\
\hline
\end{tabular}
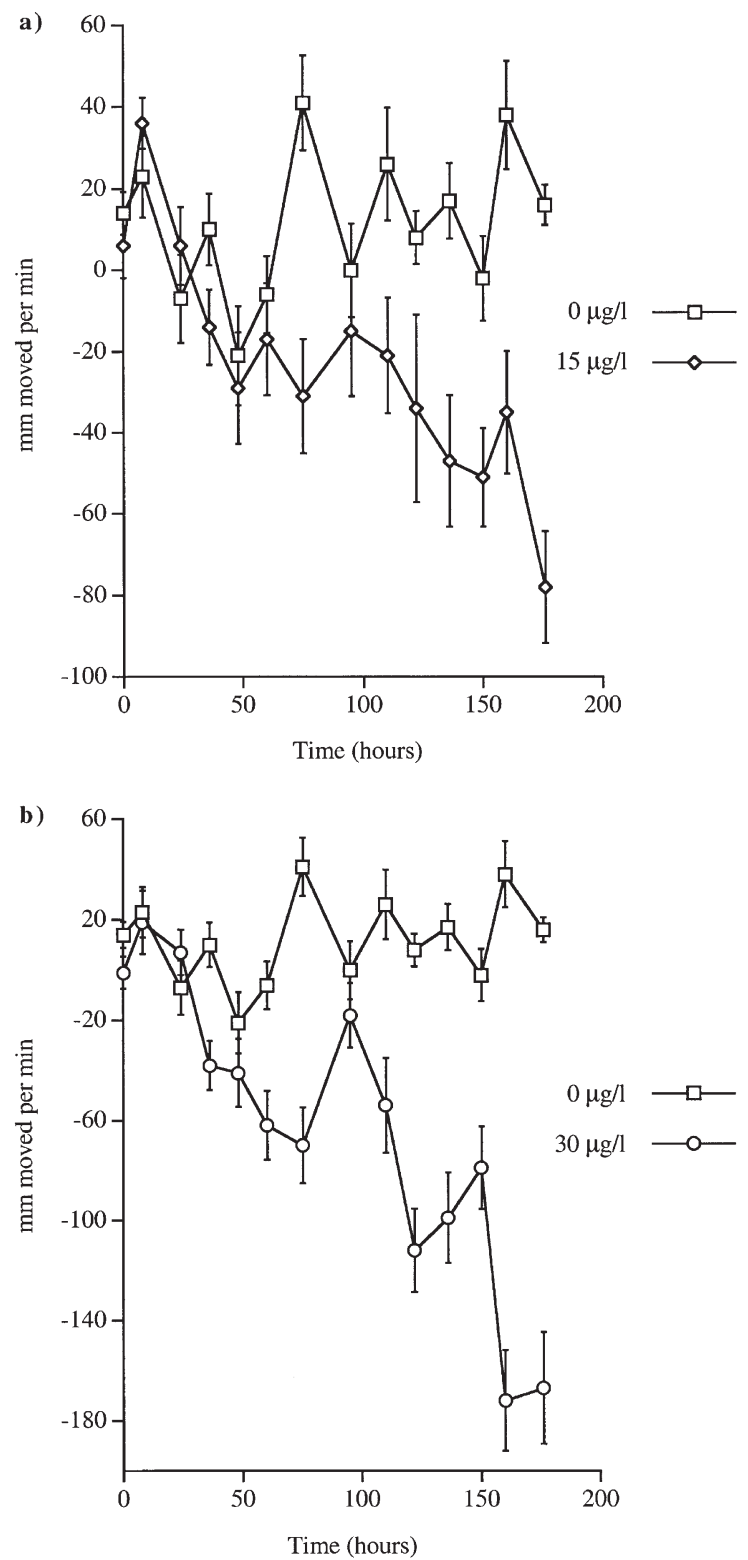

Fig. 1. Chaetogammarus marinus. Swimming stamina following exposure to $\mathrm{Cu}$ at (a) $15 \mathrm{\mu g} \mathrm{l}^{-1}$ and (b) $30 \mu \mathrm{g} \mathrm{l}^{-1}$ against a control $\left(0 \mu \mathrm{g} \mathrm{l}^{-1}\right) ; \mathrm{n}=5$; bar $=\mathrm{SEM}$

tially reduced significantly below control levels but then increased above control levels until $48 \mathrm{~h}$. It was then similar to control levels until the later stages of the test. After $161 \mathrm{~h}$, swimming was again reduced to an average of $-80 \mathrm{~mm} \mathrm{~min}^{-1}$. At $60 \mu \mathrm{g} \mathrm{PCP} \mathrm{l}^{-1}$, swimming was impaired much more rapidly. The reduction in swimming stamina continued to the end of the assay period at which time it averaged $-200 \mathrm{~mm} \mathrm{~min}^{-1}$.

Two-way ANOVA confirmed a significant difference between the treatments $(F=33.5, \mathrm{p}<0.001, \mathrm{df}=17)$. There were significant individual effects $(F=157.3, \mathrm{p}<$ $0.001, \mathrm{df}=2$ for concentration; $F=17, \mathrm{p}<0.001, \mathrm{df}=15$ 

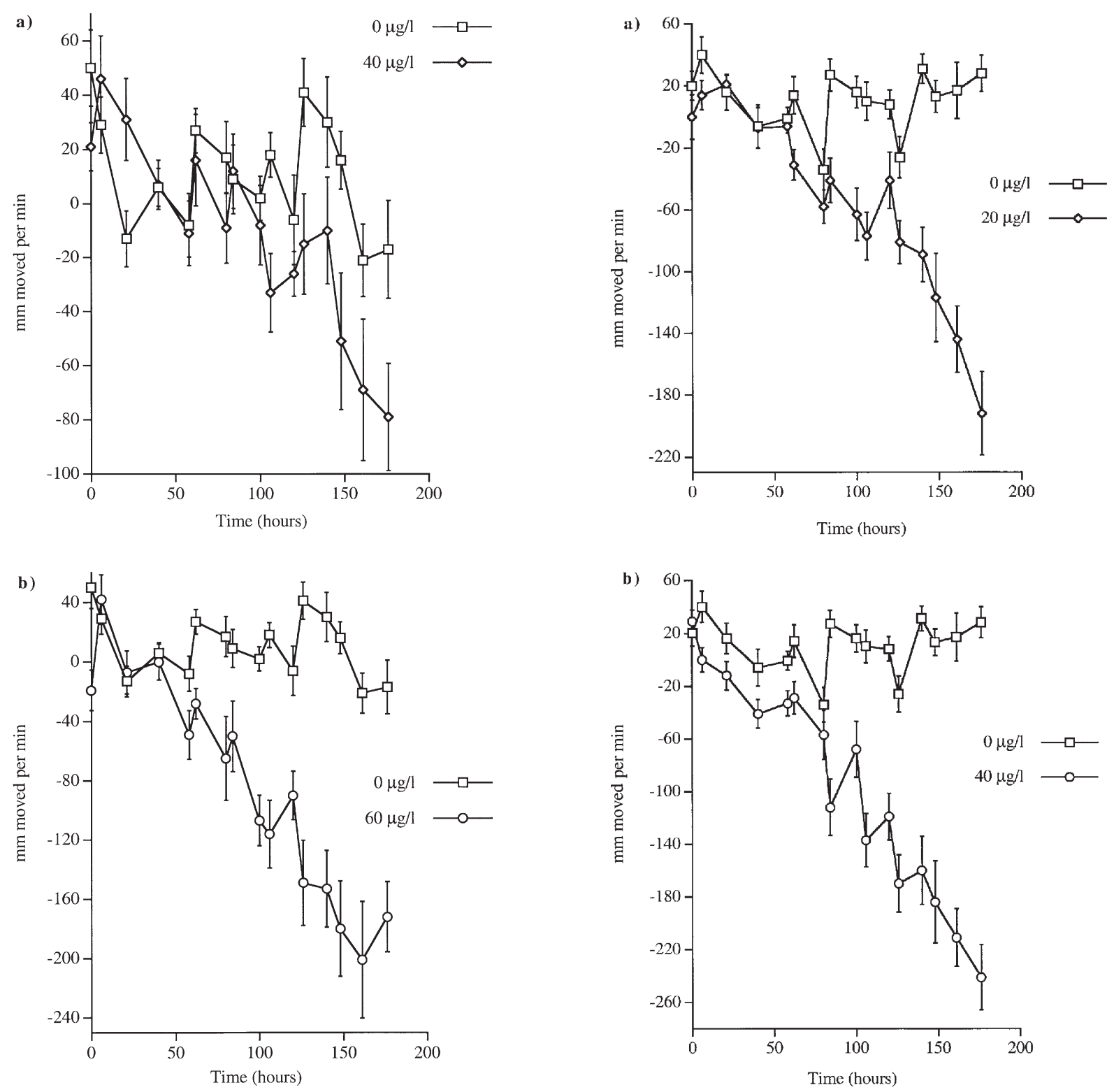

Fig. 2. Chaetogammarus marinus. Swimming stamina following exposure to pentachlorophenol (PCP) at (a) $40 \mu \mathrm{g} \mathrm{l}^{-1}$ and

(b) $60 \mu \mathrm{g} \mathrm{l}^{-1}$ against a control $\left(0 \mu \mathrm{g} \mathrm{l}^{-1}\right) ; \mathrm{n}=5$; bar $=\mathrm{SEM}$

for time) and significant time-concentration interactions $(F=5.3, \mathrm{p}<0.001, \mathrm{df}=30)$. Clear differences between the treatments were confirmed by 1-way ANOVA $(F=61.3, \mathrm{p}<0.001, \mathrm{df}=2,237)$ followed by an a posteriori LSD test, which confirmed the difference between each treatment at the $\mathrm{p}=0.05$ level.

Results of the effect of $\mathrm{B}[\mathrm{a}] \mathrm{P}$ on the swimming stamina of Chaetogammarus marinus are shown in Fig. 3. Animals exposed to $20 \mu \mathrm{g} \mathrm{B}[\mathrm{a}] \mathrm{P}^{-1}$ responded similarly to controls up to $106 \mathrm{~h}$ after which swimming was significantly reduced to $-192 \mathrm{~mm} \mathrm{~min}{ }^{-1}$ after $176 \mathrm{~h}$. At $40 \mathrm{\mu g} \mathrm{l}^{-1}$ swimming was slightly impaired initially. A

Fig. 3. Chaetogammarus marinus. Swimming stamina following exposure to benzo[a]pyrene (B[a]P) at (a) $20 \mu \mathrm{g} \mathrm{l}^{-1}$ and

(b) $40 \mu \mathrm{g} \mathrm{l}^{-1}$ against a control $\left(0 \mu \mathrm{g} \mathrm{l}^{-1}\right) ; \mathrm{n}=5$; bar $=\mathrm{SEM}$

gradual decrease in swimming was observed, which became significant after $80 \mathrm{~h}$ of exposure and reached a low of $-241 \mathrm{~mm} \mathrm{~min}{ }^{-1}$ after $176 \mathrm{~h}$.

Two-way ANOVA showed a significant difference between treatments $(F=54.3, \mathrm{p}<0.001, \mathrm{df}=17)$. There were significant concentration $(F=228.9, \mathrm{p}<0.001$, $\mathrm{df}=2)$ and time effects $(F=31, \mathrm{p}<0.001, \mathrm{df}=15)$ and significant interactions between these variables $(F=$ 9.9, $\mathrm{p}<0.001, \mathrm{df}=30$ ). Differences between each of the treatments were confirmed by 1-way ANOVA $(F=$ 56.7, $\mathrm{p}<0.001, \mathrm{df}=2,237$ ) followed by an a posteriori LSD test $(\mathrm{p}<0.05)$. 


\section{Embryo culture and development}

Growth of Chaetogammarus marinus embryos in in vitro culture under control conditions is shown in Fig. 4. Average maximum lengths and widths of embryos were plotted separately to illustrate changes in shape through the developmental stages. Observations were also recorded of the duration of each stage to hatching.

Initial average dimensions of the embryos were $642 \mu \mathrm{m}$ maximum length $\times 475 \mu \mathrm{m}$ mean maximum width. Stage 1 lasted for approximately $1.2 \mathrm{~d}$ and was marked by a decrease in average length $(600 \mu \mathrm{m})$ and increase in width $(563 \mu \mathrm{m})$. Hence the initial ovaline shape of the embryo rapidly changed to a more rounded structure. Stage 2 lasted for $3.1 \mathrm{~d}$ and Stage 3 lasted $3.7 \mathrm{~d}$ with a steady parallel increase in length and width of embryos. After Stage 3 the average embryo size was $697 \times 670 \mu \mathrm{m}$. During Stages 3 and 4 both dimensions increased markedly. Mean maximum length and width reached approximately $800 \mu \mathrm{m}$ over the $2.7 \mathrm{~d}$ period of Stage 4 . Stage 5 lasted for approximately $6 \mathrm{~d}$ with only minor changes in embryo size. Hatching was observed after approximately $16 \mathrm{~d}$ and $75 \%$ of the embryos survived to hatching.

\section{Effect of $\mathrm{Cu}, \mathrm{PCP}$ and B[a]P on embryogenesis}

The effect of $\mathrm{Cu}$ on embryo growth and development is shown in Fig. 5. Mean embryo length in individuals exposed to $20 \mu \mathrm{g} \mathrm{Cu} \mathrm{l}^{-1}$ followed a similar pattern to the control group up to $8 \mathrm{~d}$. However, the marked increase in length apparent in the control treatment in Stages 3 and 4 were not observed in the $20 \mu \mathrm{g} \mathrm{Cu} \mathrm{l^{-1 }}$

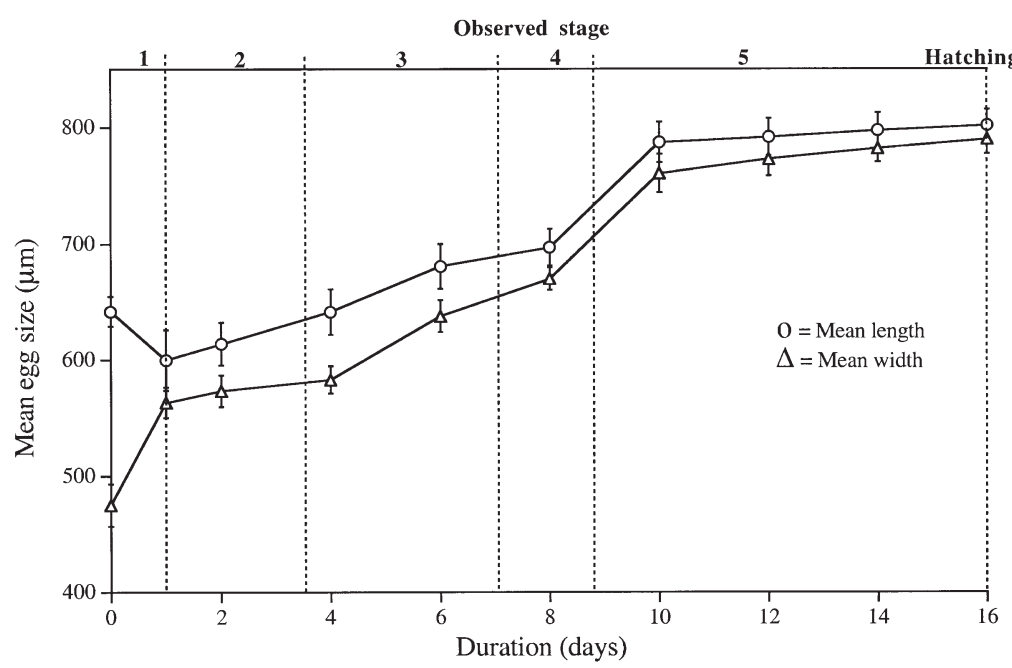

Fig. 4. Chaetogammarus marinus. Development of laboratory-cultured embryos at $20 \mathrm{psu}, 20^{\circ} \mathrm{C}$ and constant light, with observed stages of development based on Sheader \& Chia $(1970) ; n=8$; bar $=$ SEM group. Instead, a gradual increase in mean length was recorded between 8 and $20 \mathrm{~d}$ up to the expected hatching length of approximately $800 \mu \mathrm{m}$. After this time hatching was observed. During the 20 day period it was found that embryo stage durations were delayed due to the effects of $\mathrm{Cu}$. Of the initial embryos, $87.5 \%$ survived to hatching.

A similar response to that described for animals exposed to $20 \mu \mathrm{g} \mathrm{Cu} \mathrm{l}^{-1}$ was also observed in the 40

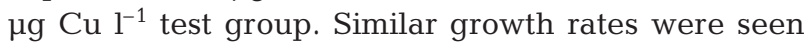
up to $8 \mathrm{~d}$. No distinct Stage 4 increase in size was noticed and between 8 and 24 d a very gradual growth was observed. Lengths of less than $800 \mu \mathrm{m}$ were measured in embryos at $24 \mathrm{~d}$ when hatching occurred. Therefore, embryo development and hatching were delayed further at the higher concentration of $\mathrm{Cu}$. However, as in the control, $75 \%$ of embryos survived to hatching.

Two-way ANOVA showed a significant difference between the treatments $(F=57, \mathrm{p}<0.001, \mathrm{df}=11)$ with significant concentration $(F=32.7, \mathrm{p}<0.001, \mathrm{df}=2)$ and time effects $(F=62.4, \mathrm{p}<0.001, \mathrm{df}=9)$ and significant interaction between these variables $(F=2.4, \mathrm{p}<$ $0.001, \mathrm{df}=18)$. A significant difference between treatments was confirmed by 1-way ANOVA $(F=7.6, \mathrm{p}<$ 0.001 , df $=2,177$ ). However, an a posteriori LSD test indicated that significant differences occurred only between the control and $40 \mu \mathrm{g} \mathrm{l}^{-1}$ treatments at the $\mathrm{p}=$ 0.05 level.

The effect of PCP on embryo development is shown in Fig. 6. At $20 \mu \mathrm{g} \mathrm{PCP} \mathrm{l}^{-1}$ the rate of increase in mean embryo lengths follows the pattern seen in the control group up to $8 \mathrm{~d}$. After $8 \mathrm{~d}$ the embryo size of the test gourp continued to increase at a very slow rate without the marked increase expected in Stages 3 and 4 . Hatching was observed after $20 \mathrm{~d}$ when embryo lengths measured an average of $775 \mu \mathrm{m}$ and $75 \%$ of embryos survived to hatching. At $40 \mu \mathrm{g} \mathrm{PCP} \mathrm{l}^{-1}$ the size of embryos decreased rapidly after $2 \mathrm{~d}$ followed by degeneration. The test was abandoned after $10 \mathrm{~d}$.

Two-way ANOVA showed a significant difference between treatments $(F=51.8$, $\mathrm{p}<0.001, \mathrm{df}=11)$. There were significant concentration $(F=110.8, \mathrm{p}<0.001, \mathrm{df}=2)$ and time effects $(F=19.5, \mathrm{p}<0.001, \mathrm{df}=9)$. The difference between treatments was confirmed by 1 -way ANOVA $(F=64.8, \mathrm{p}<$ $0.001, \mathrm{df}=2,159$ ) followed by an a posteriori LSD test, which showed that only the control and $40 \mu \mathrm{g} \mathrm{l}^{-1}$ groups were significantly different.

The effect of $\mathrm{B}[\mathrm{a}] \mathrm{P}$ on embryo development is shown in Fig. 7. On exposure to 
$20 \mu \mathrm{B}$ Ba]P $1^{-1}$, embryo growth followed the pattern seen in the control treatment up to $8 \mathrm{~d}$. After this the embryos continued to increase in size but at a slower rate than the control. However, these embryos began hatching at the same time as the control group after $16 \mathrm{~d}$ despite being significantly smaller in mean length $(752 \mu \mathrm{m})$. Again $75 \%$ of embryos survived to hatching. The size of embryos exposed to $40 \mu \mathrm{g} \mathrm{B}[\mathrm{a}] \mathrm{P}^{-1}$ declined rapidly followed by degeneration. The test was abandoned after $2 \mathrm{~d}$.

Two-way ANOVA showed a significant difference between treatments $(F=71.2, \mathrm{p}<$ $0.001, \mathrm{df}=11$ ) with significant concentration $(F=46.2, \mathrm{p}<0.001, \mathrm{df}=2)$ and time effects $(F=49.5, \mathrm{p}<0.001, \mathrm{df}=9)$. The difference between treatments was confirmed by 1-way ANOVA $(F=37.5, \mathrm{p}<0.001, \mathrm{df}=2,135)$. In this case the post hoc LSD test showed a significant difference between each of the treatments at the $\mathrm{p}=0.05$ level.

Fig. 8 illustrates the effects of $\mathrm{Cu}, \mathrm{PCP}$ and $\mathrm{B}[\mathrm{a}] \mathrm{P}$ on the time taken to complete each stage of embryonic development. One-way ANOVA showed that there was a significant difference between the treatments $(F=$ 190.5, $\mathrm{p}<0.001, \mathrm{df}=24,125)$. Results of an $a$ posteriori LSD test, performed to determine which treatment was different from which other, are illustrated by symbols in Fig. 8. Embryonic stage-time interactions connected with the same symbol are not significantly different from each other at the $\mathrm{p}=$ 0.05 level. From this it was found that in the $20 \mu \mathrm{g} \mathrm{Cu} 1^{-1}$ treatment, Stage 1 was not significantly delayed compared with control but that Stages 2, 3, 4 and 5 were. This pattern was repeated in the $40 \mu \mathrm{g} \mathrm{Cu} \mathrm{l}^{-1}$ treatment.

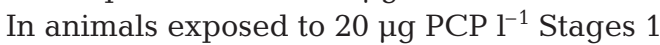
and 2 were not significantly delayed but Stages 3, 4 and 5 were. In animals exposed to $20 \mu \mathrm{g} \mathrm{B}[\mathrm{a}] \mathrm{P}^{-1}$ treatment, Stages 1 and 5 were not significantly delayed although Stages 2, 3 and 4 were.

\section{DISCUSSION}

In comparison with Gammarus duebeni, Chaetogammarus marinus was significantly more sensitive to $\mathrm{Cu}$. The $48 \mathrm{~h} \mathrm{LC}_{50}$ values were $2596 \mathrm{\mu g} \mathrm{l}^{-1}$ (Lawrence \& Poulter 1998) and $40 \mathrm{\mu g} \mathrm{l}^{-1}$, respectively. Similarly, C. marinus was more sensitive than G. duebeni to

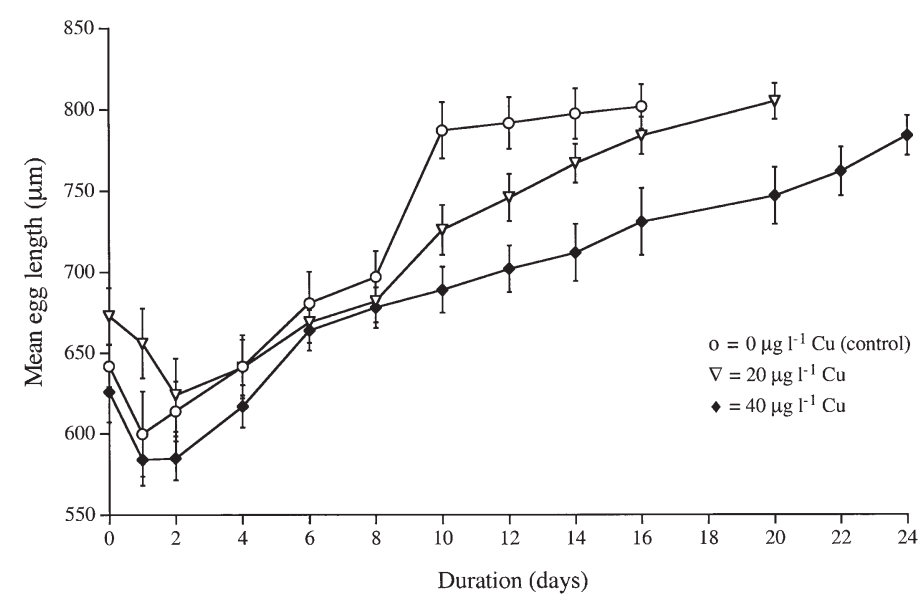

Fig. 5. Chaetogammarus marinus. Embryo development following exposure to $\mathrm{Cu}$ in culture at $20 \mathrm{ppt}$ salinity, $11^{\circ} \mathrm{C}$ and constant light; $\mathrm{n}=8$; bar $=\mathrm{SEM}$

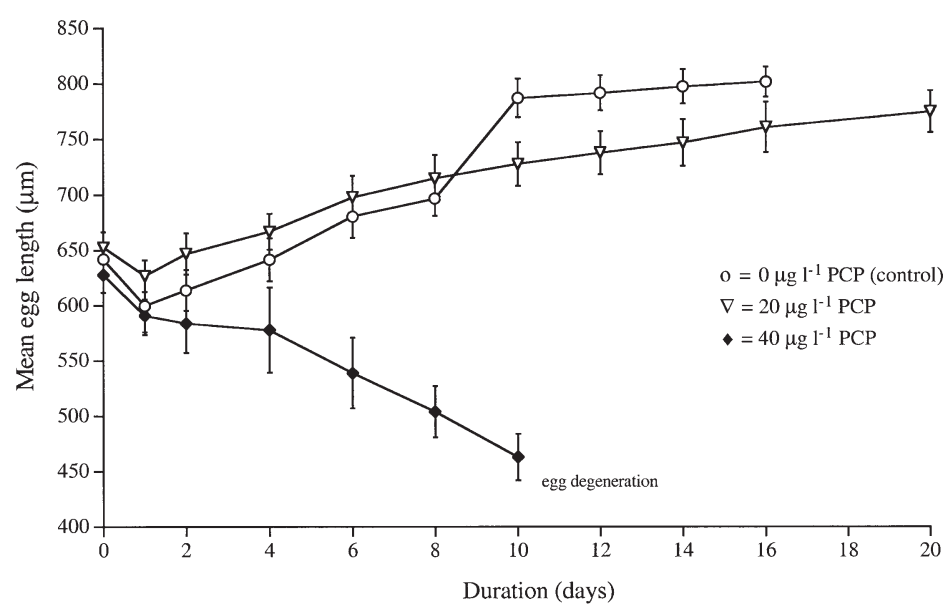

Fig. 6. Chaetogammarus marinus. Embryo development following exposure to PCP in culture at 20 ppt salinity, $11^{\circ} \mathrm{C}$ and constant light; $\mathrm{n}=8 ;$ bar $=$ SEM

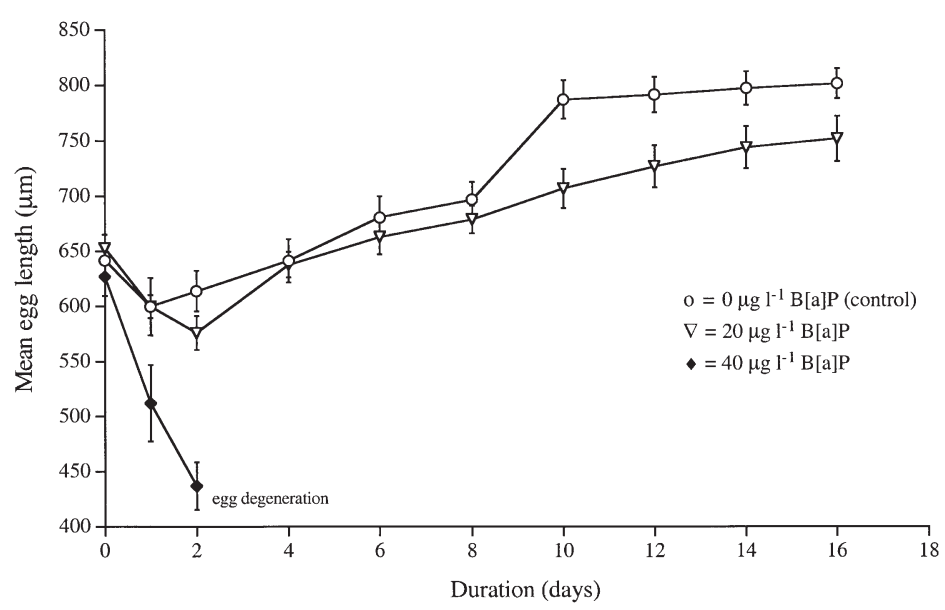

Fig. 7. Chaetogammarus marinus. Embryo development following exposure to $\mathrm{B}[\mathrm{a}] \mathrm{P}$ in culture at $20 \mathrm{ppt}$ salinity, $11^{\circ} \mathrm{C}$ and constant light; $\mathrm{n}=8$; bar $=$ SEM 


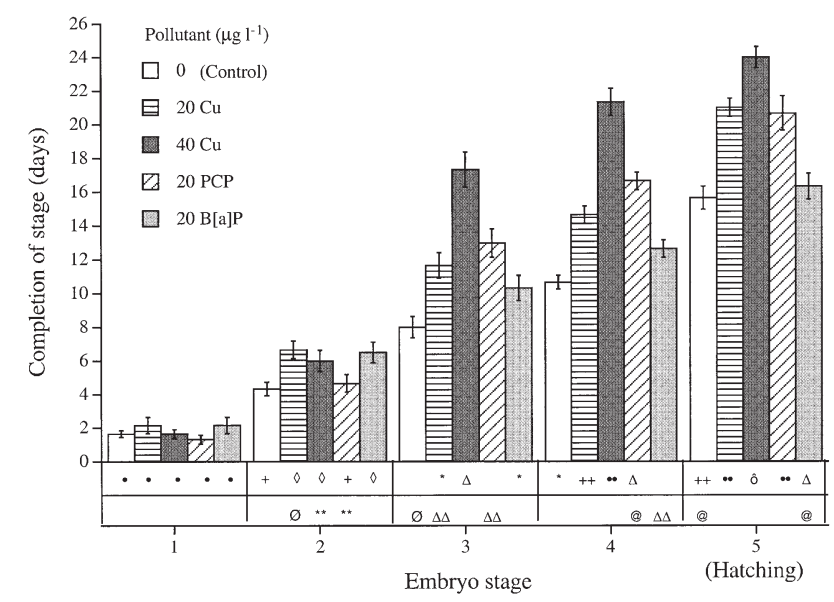

Fig. 8. Chaetogammarus marinus. Duration of embryo developmental stage following exposure to $\mathrm{Cu}, \mathrm{PCP}$ and $\mathrm{B}[\mathrm{a}] \mathrm{P}$ in vitro $\left(20 \mathrm{ppt}, 11^{\circ} \mathrm{C}\right.$ and constant light); $\mathrm{n}=8$; bar $=\mathrm{SEM}$. Embryonic stage-time interactions linked by the same symbol are not significantly different

PCP with $48 \mathrm{~h} \mathrm{LC}_{50}$ values of 363 and $723 \mu \mathrm{g} \mathrm{l} \mathrm{l}^{-1}$, respectively. However, C. marinus was less sensitive than $G$. duebeni on exposure to B[a]P with $24 \mathrm{~h} \mathrm{LC}_{50}$

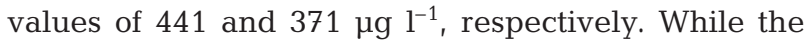
PCP values recorded for both species are higher than values recorded for the Humber estuary, the $\mathrm{Cu}$ result is significant because the $48 \mathrm{~h} \mathrm{LC}_{50}$ for $C$. marinus is lower than $\mathrm{Cu}$ concentrations occasionally recorded in estuarine waters at certain locations (National Rivers Authority 1993).

In comparison with other species, Chaetogammarus marinus appears to be more sensitive to PCP. For Artemia salina, the $48 \mathrm{~h} \mathrm{LC}_{50}$ was $5.8 \mathrm{mg} \mathrm{l}^{-1}$ and for Astacus fluviatilis it was $9 \mathrm{mg} \mathrm{l}^{-1}$ after $8 \mathrm{~d}$ of exposure. For Crangon pseudogracilis the $96 \mathrm{~h} \mathrm{LC}_{50}$ was $3.12 \mathrm{mg}$ $\mathrm{l}^{-1}$ and for Marinogammarus marinus it was $0.18 \mathrm{mg} \mathrm{l}^{-1}$ after $21 \mathrm{~d}$ of exposure (Irwin et al. 1998). However, for the estuarine dependent shrimp Penaeus aztecus the $96 \mathrm{~h} \mathrm{LC}_{50}$ was $317 \mu \mathrm{g} \mathrm{l}^{-1}$, similar to the value of $363 \mu \mathrm{g}$ $\mathrm{l}^{-1}$ after $48 \mathrm{~h}$ found here (Benfield \& Aldrich 1994).

The pattern of sensitivity seen in the $\mathrm{LC}_{50}$ tests was mirrored in the sub-lethal swimming stamina assay for $\mathrm{Cu}$ and $\mathrm{B}[\mathrm{a}] \mathrm{P}$. The swimming stamina of Chaetogammarus marinus was significantly reduced at concentrations of $15 \mu \mathrm{g} \mathrm{Cu} \mathrm{l}^{-1}, 40 \mu \mathrm{g} \mathrm{PCP}{ }^{-1}$ and $20 \mu \mathrm{g} \mathrm{B}[\mathrm{a}] \mathrm{P} \mathrm{l}^{-1}$ compared with values of $45 \mu \mathrm{g} \mathrm{Cu} \mathrm{l}^{-1}, 20 \mu \mathrm{g} \mathrm{PCP} \mathrm{l}^{-1}$ and $8 \mu \mathrm{g} \mathrm{B}[\mathrm{a}] \mathrm{P}^{-1}$ for Gammarus duebeni (Lawrence \& Poulter 1998). It should noted, however, that the assay has not yet been used to determine the Lowest Observed Effect Level (LOEL) for each species. In addition, $\mathrm{LC}_{50}$ and sub-lethal responses vary with and between species depending on time of year and physiological condition of the animals. Consequently, further studies are required to determine which of the
2 species is more sensitive to each of the representative toxicants.

What is clear from the study is that the bioassay is applicable to both species and in the case of $\mathrm{Cu}$ can detect changes in the swimming behaviour of the individuals at environmentally relevant concentrations. Concentrations of $\mathrm{Cu}$ at the mouth of the Humber have been recorded as high as $300 \mu \mathrm{g} \mathrm{l}^{-1}$ and in some of the docks concentrations as high as $50 \mathrm{\mu g} \mathrm{l}^{-1}$ were recorded (National Rivers Authority 1993). Furthermore, in 1997 and 1998 Brough, New Holland, Albert Dock and Saltend all failed to meet compliance with EQS for $\mathrm{Cu}$ with maximum concentrations as high as $11.4 \mathrm{\mu g} \mathrm{l}^{-1}$ (Environment Agency 1998). This is very similar to the concentration found to affect swimming in this study. While these are maximum concentrations, Edwards et al. (1991) have shown that the effect of peak rather than mean toxic concentrations may be important in assessing pollution impact. This highlights the potential significance of episodic pollution events in an environment (Taylor et al. 1994).

$\mathrm{B}[\mathrm{a}] \mathrm{P}$ is not specifically recorded on the Humber, although sediment hydrocarbon levels are high with an average of $343 \mathrm{mg} \mathrm{kg}^{-1}$ dry weight up to a maximum of $885 \mathrm{mg} \mathrm{kg}^{-1}$ (National Rivers Authority 1993). On the Thames River, concentrations of this pollutant have been recorded up to $0.35 \mathrm{\mu g} \mathrm{l}^{-1}$ (Irwin et al. 1998). It is still to be determined whether the swimming stamina assay is sensitive to these concentrations of $\mathrm{B}[\mathrm{a}] \mathrm{P}$.

On the Humber, concentrations of PCP are usually below their EQS of $2 \mu \mathrm{g} \mathrm{l}^{-1}$ but maximum levels $<5 \mu \mathrm{g}$ $\mathrm{l}^{-1}$ were recorded at New Holland and $<2 \mu g \mathrm{l}^{-1}$ at Killingholme in 1996 (Environment Agency 1998). These levels are again in the same order of magnitude as those shown to affect swimming of Chaetogammarus marinus. However, until LOELs are determined, it is not possible to confirm whether the concentrations of PCP recorded in the environment are likely to affect the behaviour of these gammarids. The assay does, however, seem to be as sensitive as others to PCP. For example, using an avoidance behaviour assay Benfield \& Aldrich (1994) found that Penaeus aztecus was able to detect and avoid PCP at a concentration of $91 \mu g \mathrm{l}^{-1}$.

The results also support the contention that these behavioural assays are useful in ecotoxicological testing (Miller 1980, Gerhardt 1995, Lawrence \& Poulter 1996, 1998, Lawrence \& Hemingway 2001). They are rapid indicators of stress and allow an evaluation of the functional integrity of a number of physiological processes including respiration, energy metabolism, motor function and swimming coordination.

Swimming behaviour may be particularly useful in studying estuarine species because of the individual's 
need to maintain an optimal position independent of currents and tides. Effects on swimming may have implications for both position maintenance and survival (Roast et al. 2000a,b) especially for Chaetogammarus marinus, which is known to be a weak competitor at low salinities (Pinkster \& Broodbaker 1980). Several inter-tidal and in-faunal amphipods have been shown to exhibit rheotropic response to water flow, which may be under endocrine control (Fincham 1972). Furthermore, Handy et al. (1999) have recently proposed a metabolic trade-off between locomotion and detoxification in rainbow trout (Onchorhynchus mykiss). This suggests a link between sub-cellular responses to pollution and physiology and behaviour through partitioning of resources in a way to maintain growth.

In this study, embryogenesis was also significantly impaired by each of the toxicants. Both $40 \mu \mathrm{g} \mathrm{Cu} \mathrm{l}^{-1}$ and $20 \mu \mathrm{g} \mathrm{PCP} \mathrm{l}^{-1}$ significantly increased the time to hatching by 4 or more d. In contrast, $20 \mu \mathrm{g} \mathrm{B}[\mathrm{a}] \mathrm{P}^{-1}$ did not extend the period of embryogenesis but led to significantly smaller embyos after the normal developmental period. In addition, however, there were significant stage effects. Copper at a concentration of $20 \mathrm{\mu g} \mathrm{l}^{-1}$ significantly delayed Stages 2 to 5 of embryogenesis. PCP at $20 \mu \mathrm{g} \mathrm{l}^{-1}$ significantly delayed Stages 3 to 4 of development and B[a]P Stages 2 to 4 . Consequently, early embryo cleavage associated with Stage 1 appeared insensitive to any of the pollutants. Stages 2 to 4 , in which the germinal disc, dorsal organ rudiments, cordal furrows, appendage rudiments and segments, and eye and heart develop, were all prolonged in embryos exposed to each of the toxicants. However, closer examination of the data showed that the length of time taken to complete Stage 5 (in which pigment forms in the eye, the heart begins to beat and muscular movement begins) was reduced in each treatment compared with the control, except for $20 \mu \mathrm{g}$ $\mathrm{Cu} \mathrm{l}^{-1}$. This, in part, compensated for the delays seen in the earlier stages.

Delayed embryogenesis may reduce the chances of survival of offspring through increasing the period of a sensitive and vulnerable life stage. For example, eggs released into the plankton are more likely to be prayed on if development is extended. However, in Chaetogammarus marinus, brooding of the developing embryo by the female may compensate for this through the protection provided by the mother. Likelihood of survival may be further affected, however, by delaying the release of the embryo into the environment. Timing of reproduction is such that juveniles are thought to be released at a time allowing optimal survival through availability of food, lack of predator, or some other mechanism (Olive et al. 1990).
$\mathrm{B}[\mathrm{a}] \mathrm{P}$ did not extend the period of embryogenesis but the hatched juveniles were significantly smaller than those from controls. Again, this may have implications for the future survival and breeding potential of the offspring. Many studies have shown that reduced size or birth weight can affect survivability (Kolding \& Fenchel 1981).

$\mathrm{B}[\mathrm{a}] \mathrm{P}$ has recently been identified as an endocrine disrupter (Safe 1995). The importance of this group of chemicals has been highlighted in recent years with many studies showing effects on reproduction, particularly in fish. With the exception of Tributyltin (TBT) effects on Nucella lapillus and other molluscs, far less is known about the impact of endocrine disrupters on invertebrates. Development of assays that assess their impact on embryogenesis, such as that developed here, offer one approach but others may be available. For example, the rheotropic response to water flow may be under endocrine control (Fincham 1972) and consequently the swimming response of Chaetogammarus marinus may have been affected through endocrine disruption rather than an energetics pathway on exposure to $\mathrm{B}[\mathrm{a}] \mathrm{P}$.

The different manifestations of impact on embryogenesis, either delayed development or reduced size of hatched offspring, suggest that the pollutants may be affecting the process in different ways. Alternatively, both processes may occur for each pollutant but in a dose dependent manner. The growth of embryonic structures is caused by the conversion of egg protein (Sheader 1983). The finding that each toxicant delayed Stages 2 to 4 of embryogenesis indicates an impact on developmental processes. As an endocrine disrupter, $\mathrm{B}[\mathrm{a}] \mathrm{P}$, may affect the vitellogenic process (Safe 1995). However, embryos were exposed to each pollutant only after vitellogenesis had been completed. Therefore, it is not clear what the mechanism is by which the contaminants affect the developing embryo.

Understanding the potential impacts of endocrine disrupters and embryotoxic compounds on invertebrates is critical because of the ecological implications of such effects. Many estuarine invertebrates, including amphipods, provide an important food source for juvenile commercial fish and birds. Costa \& Elliott (1991) have highlighted the central role of small epibenthic crustaceans, including amphipods and shrimp, as the main link between detritus and fishes. Indeed, in the specific case of the Humber estuary it is gammarids and mysids that form the dominant prey within the foodweb, occurring in the diet of most fish species (Marshall 1995). Consequently, any impact on the reproduction and fecundity of these invertebrates may have significant ramifications on estuarine food chains and secondary production. 
Embryos of gammarids have some ability to regulate the passage of water and ions over their membranes (Morritt \& Spicer 1996). This is supported by the observation that juveniles in $40 \mu \mathrm{g} \mathrm{Cu} \mathrm{l}^{-1}$ survived to hatching despite this being the $48 \mathrm{~h} \mathrm{LC}_{50}$ determined for the adults. This suggests that reduced permeability of the embryo wall enables the embryo to withstand the effect of $\mathrm{Cu}$ that is lethal to the adult.

Both swimming stamina and embryonic development have been found using Chaetogammarus marinus to be sensitive to a range of representative pollutants. In the case of $\mathrm{Cu}$, both responses are sensitive at environmentally realistic concentrations experienced on the Humber estuary. However, the LOELs are yet to be determined for $\mathrm{Cu}, \mathrm{PCP}$ or $\mathrm{B}[\mathrm{a}] \mathrm{P}$. It is not yet possible to say which of the responses is the more sensitive to any of the toxicants used in the study.

The results of this study provide further evidence to support the use of Gammaridae in ecotoxicology studies particularly in estuarine areas where the choice of appropriate species is limited. The swimming stamina assay has the advantage that it is quick and shows an impact on a process that requires integration of a number of physiological and neural parameters. Embryonic development is interesting first because it appears that it can be used as a sensitive bioassay in a stage specific manner but second because it can also be used to examine the underlying mechanism of toxic impact. This is particularly relevant because effects on reproduction and fecundity, including larval development and survival, are seen as the crucial stage in the hierarchic range of responses linking subcellular and molecular effects in the individual with population level change.

\section{LITERATURE CITED}

Baron MG, Podrabsky T, Ogle S, Ricker RW (1999) Are aromatic hydrocarbons the primary determinants of petroleum toxicity to aquatic organisms? Aquat Toxicol 46: 253-268

Benfield MC, Aldrich DV (1994) Avoidance of PCP by postlarval brown shrimp (Penaeus aztecus) (Decapoda, Penaeidae) in a laminar-flow choice chamber. Can J Fish Aquat Sci 51:784-791

Bryan GW, Langston WJ (1992) Bioavailability, accumulation and effects of heavy metals in sediments with special reference to United Kingdom estuaries: a review. Environ Pollut 76:89-131

Bulnheim HP (1979) Comparative studies on the physiological ecology of five euryhaline Gammarus species. Oecologia 44:80-86

Costa MJ, Elliott M (1991) Fish usage and feeding in two industrialised estuaries: the Tagus, Portugal and the Forth, Scotland. In: Elliott M, Ducrotoy JP (eds) Estuaries and coasts: spatial and temporal intercomparisons. Olsen and Olsen, Fredensborg, p 289-297

Edwards RW, Ormerod SJ, Turner C (1991) Field experi- ments to assess biological effects of pollution episodes in streams. Verh Int Ver Limnol 24:1734-1737

Eisler R (1989) PCP: hazard to fish, wildlife and invertebrates. Fish Wildlife Serv Biol Rep 85:63

Environment Agency (1998) Humber Estuary state of the environment 1998 technical report. Environment Agency, Bristol

Fincham AA (1972) Rhythmic swimming and rheotropism in the amphipod Marinogammarus marinus (Leach). J Exp Mar Biol Ecol 8:19-26

Finney DJ (1980) Statistics for biologists. Chapman and Hall, London

Gerhardt A (1995) Monitoring behavioural responses to metals in Gammarus pulex (L) (Crustacea) with impedance conversion. Environ Sci Pollut Res 2:15-23

Handy RD, Sims DW, Giles A, Campbell HA, Musonda MM (1999) Metabolic trade-off between locomotion and detoxification for maintenance of blood chemistry and growth parameters by rainbow trout (Oncorhynchus mykiss) during chronic dietary exposure to copper. Aquat Toxicol 47:23-41

Irwin RJ, Van Mouwerik M, Stevens L, Seese MD, Basham W (1998) Environmental contaminants encyclopaedia. National Parks Service, Water Resource Division, Fort Collins, $\mathrm{CO}$

Kolding S, Fenchel TM (1981) Patterns of reproduction in different populations of five species of amphipod genus Gammarus. Oikos 37:167-172

Lawrence AJ (1996) Environmental and endocrine control of reproduction in two species of polychaete: potential bioindicators for global climate change. J Mar Biol Assoc UK 76:247-250

Lawrence AJ, Hemingway K (eds) (2001) Impact of marine xenobiotics on European commercial fish: molecular effects and population responses. EU FAIR Tech Rep, p 282

Lawrence AJ, Poulter C (1996) The potential role of the estuarine amphipod Gammarus duebeni in sub-lethal ecotoxicology testing. Water Sci Technol 34:93-100

Lawrence AJ, Poulter C (1998) Development of a sub-lethal pollution bioassay using the estuarine amphipod Gammarus duebeni. Water Res 32:569-578

Marshall S (1995) The structure and functioning of the fish assemblage of the Humber estuary, UK. PhD thesis, University of Hull

McLusky D (1989) The estuarine ecosystem, 2nd edn. Blackie and Sons Ltd, London

Miller DC (1980) Some applications of locomotor response in pollution effects monitoring. Rapp PV Reun Cons Int Explor Mer 179:154-161

Morritt D, Spicer JI (1995) Changes in the pattern of osmoregulation in the brackish water amphipod Gammarus duebeni Lilljeborg (Crustacea) during embryonic development. J Exp Zool 273:271-281

Morritt D, Spicer JI (1996) The culture of eggs and embryos of amphipod crustaceans: implications for brood pouch physiology. J Mar Biol Assoc UK 76:361-376

National Rivers Authority (1993) The quality of the Humber Estuary 1980-1990. Report of the National Rivers Authority. NRA, Leeds

Olive PJW, Clark S, Lawrence AJ (1990) Global warming and seasonal reproduction. Perception and transduction of environmental information. In: Hoshi M, Yamashita $\mathrm{O}$ (eds) Advances in invertebrate reproduction 5. Elsevier, Amsterdam, p 265-270

Philips DJH (1980) Quantitative aquatic biological indicators: their use to monitor trace metals and organochlorine pollution. Applied Science Publishers, Barking 
Pinkster S, Broodbaker NW (1980) The influence of environmental factors on distribution and reproductive success of Eulimnogammarus obtusata (Dahl 1938) and other estuarine gammarids. Crustaceana Suppl 6:225-241

Ritz DA (1980) Tolerance of intertidal amphipods to fluctuating conditions of salinity, oxygen and copper. J Mar Biol Assoc UK 60:489-498

Roast SD, Thompson RS, Widdows J, Jones MB (1998) Mysids and environmental monitoring: a case for their use in estuaries. Mar Freshw Res 49:827-832

Roast SD, Thompson RS, Donkin P, Jones MB (1999) Toxicity of organophosphate pesticides chlorpyrifos and dimethoate to Neomysis integer (Crustacea: Mysidacea). Water Res 33:319-326

Roast SD, Widdows J, Jones MB (2000a) Mysids and trace metals: disruption of swimming as a behavioural indicator of environmental contamination. Mar Environ Res 50: 107-112

Roast SD, Widdows J, Jones MB (2000b) Disruption of swimming in the hyperbenthic mysid Neomysis integer (Peracarida: Mysidacea) by the organophosphate pesticide chlorpyrifos. Aquat Toxicol 47:227-241

Safe S (1995) Modulation of gene expression and endocrine response pathways by 2,3,7,8-tetrachlorodibenzo-p-dioxin (TCDD) and related compounds as antiestrogens: characterisation and mechanism of action. Pharmacol Toxicol 69:400-409

Sexton EW (1928) On the rearing and breeding of Gammarus in laboratory conditions. J Mar Biol Assoc UK 15:33-55

Editorial responsibility: Otto Kinne (Editor),

Oldendorf/Luhe, Germany
Sheader M (1983) The reproductive biology and ecology of Gammarus duebeni (Crustacea: Amphipoda) in southern England. J Mar Biol Assoc UK 63:517-540

Sheader M (1995) Factors influencing egg size in the gammarid amphipod Gammarus insensibilis. Mar Biol 124: 519-526

Sheader M, Chia FS (1970) Development, fecundity and brooding behaviour of the amphipod Marinogammarus obtusata. J Mar Biol Assoc UK 50:1079-1099

Skadsheim A (1984) Coexistence and reproductive adaptation of amphipods: the role of environmental heterogeneity. Oikos 43:94-103

Steele VJ (1981) the effect of photoperiod on the reproductive cycle of Gammarus lawrencianus Bousfield. J Exp Mar Biol Ecol 53:1-7

Taylor E, Jones D, Maund S, Pascoe D (1993) A new method for measuring feeding activity of Gammarus pulex (L). Chemosphere 26:1375-1381

Taylor E, Rees E, Pascoe D (1994) Mortality and drift related response of the freshwater amphipod Gammarus pulex (L) exposed to natural sediments, acidification and copper. Aquat Toxicol 29:83-101

Vlasblom AG (1969) A study of a population of Marinogammarus marinus (Leach) in the Oosterschelde. Neth J Sea Res 4:317-338

Vlasblom AG, Bolier G (1971) Tolerance of the embryos of Marinogammarus marinus and Orchestia gammarella to lowered salinities. Neth J Sea Res 5:49-62

Submitted: December 4, 2000; Accepted: May 25, 2001

Proofs received from author(s): November 1, 2001 